\title{
Perceptions of Students for Sudden Movement from Face-to- Face Teaching to Online Learning Environment: A Regional Study in Conditions Affected by the COVID-19 Pandemic
}

\author{
Valentina Haxhiymeri (Xhafa) \\ Faculty of Education Sciences, University of Elbasan \\ "Aleksandër Xhuvani", Albania
}

\section{Abstract}

This paper is focused on exploring the learning experiences of students of Faculty of Education Sciences, University of Elbasan, Albania, during the period of sudden movement from teaching in auditorium to the online learning environment due to the COVID-19 pandemic. The purpose of the study was to identify the positive and negative aspects of online learning as experienced by students, as well as to find out their preference for the most appropriate form of higher education delivery (face-to-face, hybrid, online) for young people of digital age. The methodology used in this study included an item-based questionnaire to collect data which was developed through a web-based application known as Google Forms and was delivered to students via Internet. Qualitative and quantitative analysis was undertaken for the answers obtained by the open-ended and closed-ended questions. The results of the study showed that the biggest challenge for all students was the immediate adaptation to the form of distance learning. Most of them had perceived the online learning dominated more by negative experiences than positive ones. The study concluded that new reality created by COVID-19 tested the current capacity of Higher Education Institutions regarding the ICT integration process in teaching. As this process was progressing very slowly, universities were found unprepared to transfer the teaching process from the auditorium to the online environment with the same quality. In order to meet the demands of the future, it is imperative that every university to plan strategically the increase investment towards its digital transformation.

Keywords: student learning experiences, online learning, face-to-face teaching, hybrid teaching model, higher education digital transformation.

\section{Introduction}

Online learning has shown significant growth over the past decade at most universities in the world. According to a Tracking Distance Education Report in the 
United States (Seaman, J., et al., 2018) it was estimated that more than half of students $(52.8 \%)$ took at least one distance course. Referring to the recent Online Education Trends Report (Venable, M., 2020) it is learned that the number of students enrolled in "at least one distance education course" is increased by more than $6 \%$ (Ginder, et al., 2018).

In Albania, except rare cases of experimenting with online platforms as a part of Erasmus+ projects, there are no other data on the development of online learning in higher education before the onset of COVID-19 pandemic.

Due to the situation created by COVID-19, all universities in Albania were being moved rapidly from face-to-face teaching setting to online learning environment. The use of online model was considered by the academic staff and higher education management authorities as the only solution of the moment in the extraordinary conditions of social isolation.

The focus of this paper was to explore the academic experience of transition from face-to-face teaching to online learning, based on the perceptions of students who were attending the study programs in the field of teaching in the Faculty of Education Sciences, at the University of Elbasan, Albania.

The notion that learning only takes place in real environments (e.g., classrooms, laboratories) has since been challenged and overtaken by the use of the Internet and network technologies (Stacey et al, 2004). The access to digital technologies that allow interaction between subjects at different times and spaces has opened precedents for new ways of teaching and learning. One of them was the creation of the Virtual Learning Environment (VLE), an electronic classroom, interactive, flexible and decentralized, in which learners and tutors participate in online interactions of various kinds, including online learning (Carmo\&Franco, 2019).

Online learning or E-learning (Glossary of Online Learning Terms, 2019) refers to an instructional strategy in which the learners are geographically separated from the instructor, and the instruction is delivered totally through the computer (WCET, 2004)1. Studies have identified practical and pedagogical benefits from applying online teaching to universities. The online classes are seen as an effective way with reduced costs to offer study courses. They allow more flexibility, particularly to the non-traditional students who may have family or work obligations (Arias J., Swinton, J., Anderson, K., 2018). The accessibility of the internet and flexibility of online courses have made online education an integral part of higher education (Kebritchi, et al., 2017; Devine, J., Gordon, M., 2020).

However, moving from face-to-face teaching to online teaching is a complex and challenging endeavour for the higher education institution, academic staff and students as well. Adapting to the online learning environment takes time, energy,

${ }^{1}$ Cited from Mansour, B. E., Mupinga, D. M., (2007) 
patience, and a willingness to try new teaching strategies and new tools (Boettcher, J., Conrad, M., 2010).

Given that the online education is expected to be critical for the future of higher education institutions, this paper is also interested in examining students' preferences towards the various forms/modes of education delivery at the university (face-to-face, online, hybrid). A better understanding of this trend can help the higher education institutions, in particular the faculties that prepare future teacher to build a new culture of teaching and learning that best responds to the needs of digital age students.

\section{Materials and Methods}

This study was conducted with students who were attending a Bachelor or Master Study Program in the field of teaching for various specialty subjects, in Faculty of Education Sciences, University of Elbasan, Albania. All study programs were offered full time for the academic year 2019-2020 which means that they would be developed through the direct form of teaching in the auditorium.

This study was designed to explore the students` experience affected by the sudden movement from teaching in auditorium to online learning environment during the period of social isolation caused by COVID-19 pandemic.

The purpose of the study was to identify the positive and negative aspects of online learning as experienced by students as well as to find out their preference for the most appropriate form of higher education delivery (face-to-face, hybrid, online) for young people of digital age.

The methodology used in this study was consistent with social research and the previous studies with similar topics. After reviewing the relevant literature, an itembased questionnaire was developed to collect data through a web-based application known as Google Forms. In order to ensure the validity of the questionnaire, its first draft was subjected to a review and pre-testing (pilot) process on a small size of representatives from the students' population to which it was going to be administered. After that, the final questionnaire was developed with 7 items covering the following components: (1) The data on the academic profile of the participants; (2) Students perceptions towards online learning; (3) Level of mastery of the digital competence; (4) The web-based applications most used for online learning; (5) The difficulties with online learning; (6) Students' preferences towards the various modes/forms of higher education delivery (face-to-face, online, hybrid) in the future, and (7) Something else to add.

In the questionnaire were used a total of 5 closed-ended questions with the option to choose from a set of pre-determined answers, including a five-point Likert Scale as well, and 2 open-ended questions that allows to be formulated the response as a text written by the own student. 
This questionnaire was delivered to 118 students via the Internet respecting the anonymity of each study participant in order to get more accurate information. A total of $86(n=86)$ questionnaires $(73 \%)$ were collected in return, where 70 of them $(81 \%)$ were completed by students who were pursuing a Master Degree and 16 questionnaires (19\%) were completed by students who were pursuing a Bachelor Degree. The questionnaire started in early May, 2020 and after two reminders, data collection ended in early June, 2020.

Quantitative analysis was undertaken for the results derived from closed-ended questions which were expressed as percentage of occurrence per item and were calculated by the Google Forms Program. The answers obtained in the open-ended questions were extracted from the written text and were analyzed quantitatively for repeated themes and finally summarized.

\section{Results}

The core findings of the study were presented statistically, analyzed and discussed as follows. The data collected by the questionnaire were expressed as percentage of occurrence per item and were organized using visual aids in order to make the results more easily understandable.

The response rate in this study was $73 \%(n=86)$ or a total of 86 responses out of the 118 online delivered questionnaires were returned. This result could be justified not only by the fact that participation in the study was voluntary, but also by the isolation situation caused by COVID-19, where not all students could have access or a stable internet connection from home.

\subsection{Students' perceptions towards online teaching/learning}

The study results regarding the students` perceptions for the sudden movement from teaching in the auditorium to online learning are summarized in Figure 1.

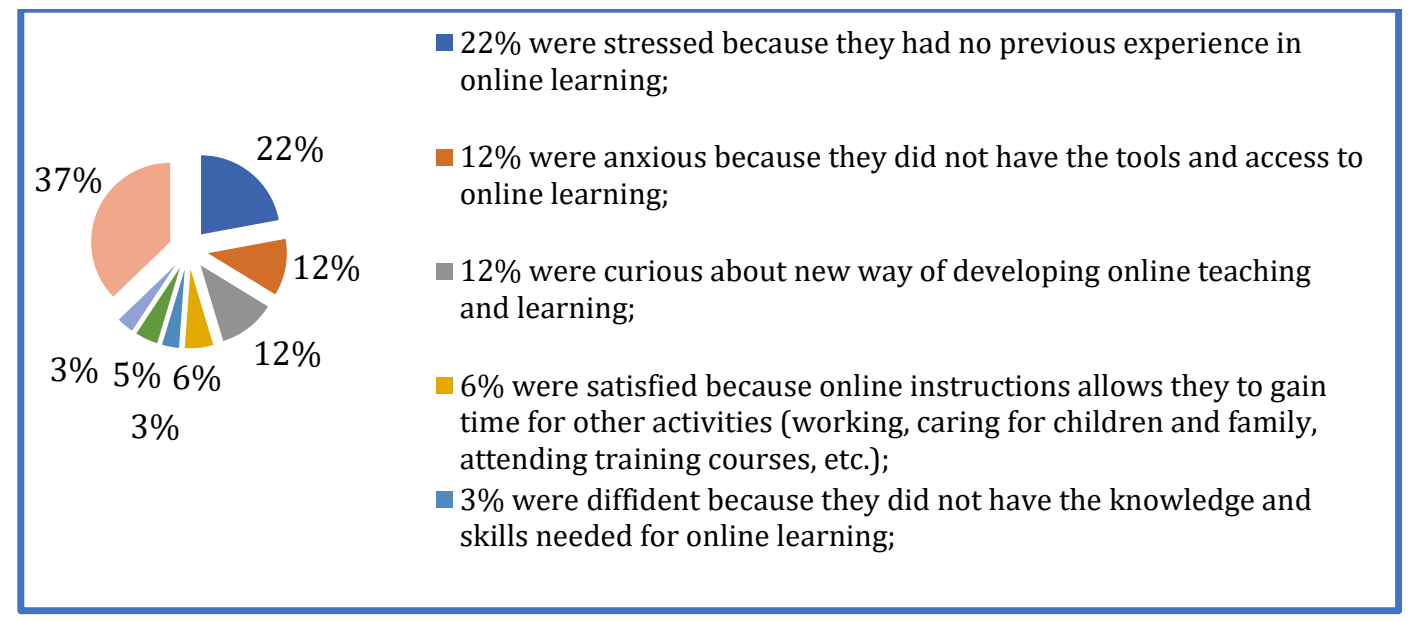


Figure 1: The perception of students for the sudden movement from teaching in the auditorium to online learning.

As it can be seen from Figure 1, approximately $23 \%$ of students reported the positive experiences in online learning which were expressed with attitudes such as positivity (5\%), curiosity (12\%), satisfying (6\%).

Positive experiences reported by students toward online learning were mainly related to factors such as the attractive nature of the internet-based learning model, its flexibility that allowed individuals to gain time for other activities, self-confidence about the knowledge and practical skills gained in the field of ICT.

Almost $77 \%$ of students reported the negative experiences in online learning. They showed that had found themselves in difficulty (37\%), stress $(22 \%)$, anxiety (12\%) diffident (3\%), and loneliness (3\%).

Negative experiences were mainly related to factors such as lack of previous experience in online learning, lack of available digital tools and internet access, lack of needed knowledge and digital skills, feeling of isolation and lack of interaction with classmates, difficulty understanding the specific lessons and assignments in terms of independent learning.

A comparison of study findings showed that the new online learning situation was perceived by the vast majority of students $(77 \%)$ as dominated more by negative experiences than by positive ones.

\subsection{Level of mastery of digital competence rated by the students themselves}

One of the issues investigated in this study was also the assessment of students' level of digital competences by their own perception. A five-point Likert Scale was used to assess the level of mastery of students' digital competence. The competence levels were ranged from a minimum of 1 point (very poor) to a maximum of 5 points (excellent). The statistical data are presented in Figure 2.

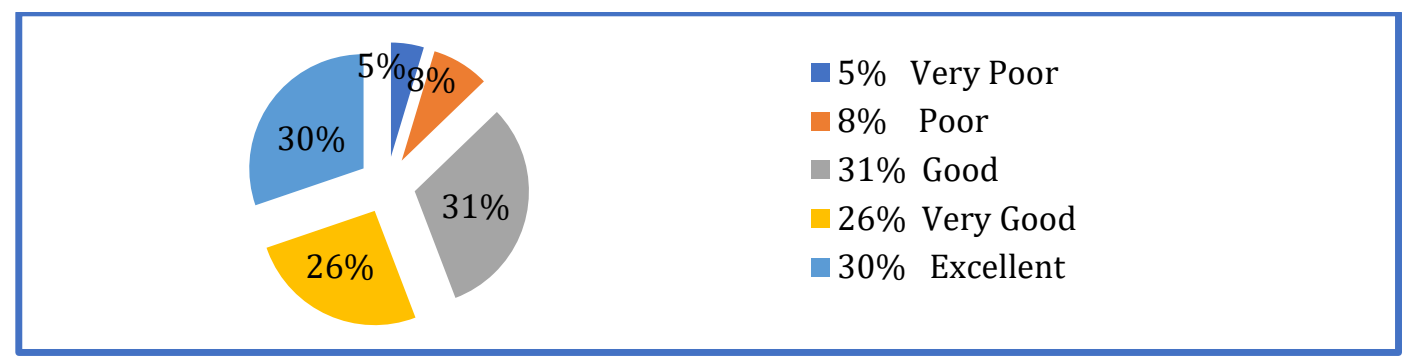

Figure 2: Level of mastery of students` digital competence rated by students themselves.

As can be seen from the data presented in Figure 2, more than half of respondents $(56 \%)$ in total rated themselves at an excellent level (30\%) and a very good level 
(26\%) of digital competence. There were $31 \%$ of respondents who rated themselves at a good level of digital competence. Only $13 \%$ of all respondents self-reported a poor level (8\%) and a very poor level (5\%) of digital competence.

To summarize, there were $87 \%$ of all students who admitted that they had a high level of digital competence, compared to $13 \%$ who admitted that they did not possess it sufficiently.

\section{Web-based applications more used for online learning}

One of issues included in questionnaire for study purposes was the investigation of web-based applications more used for online learning. Statistical data are presented in Figure 3.

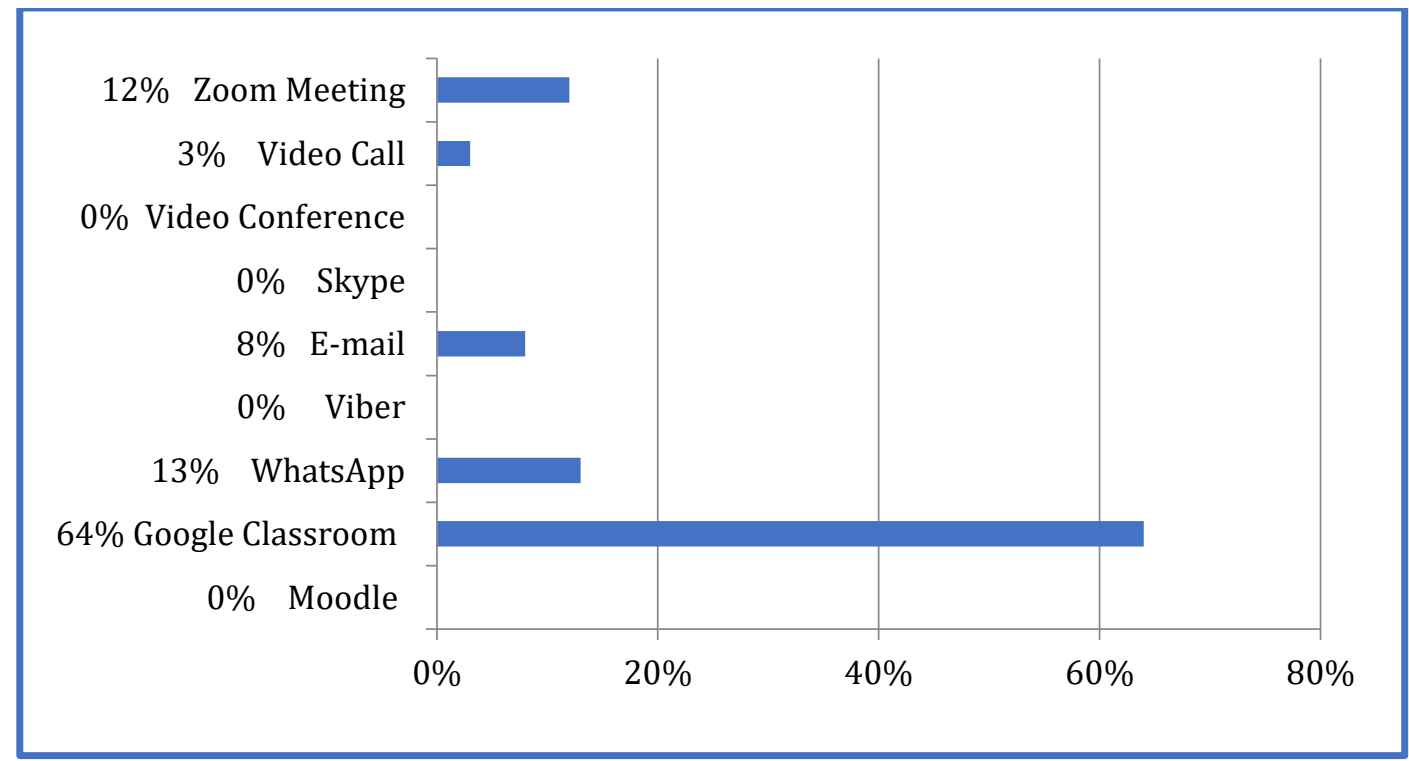

Figure 3: The more used web-based applications for online learning

As is indicated in Figure 3, there were some of types of web-based applications more used for online learning during period when the teaching in auditorium was interrupted due to COVID-19 pandemic. Majority of respondents (64\%) reported the use of Google Classroom for online learning. There were $13 \%$ who reported the use of WhatsUpp application and 12\% declared the use of Zoom Meeting. The web-based applications rarely used for online learning were E-mail (8\%), followed Video Call (3\%).

The results showed that more used web-based applications for online learning was Google Classroom, followed by WhatsApp and Zoom Meeting. In particular, Google Classroom and Zoom Meeting are recognized as the cost-effective teaching platforms that can be easily used if professors and students would have an adequate level of digital competence. 


\section{The difficulties with online learning}

The study also focused on identifying potential difficulties that students could have encountered during online learning. The data obtained from students in response to the open-ended questions were extracted from written text and were analyzed quantitatively for repeated themes, as well as were categorized and presented in the Figure 4.

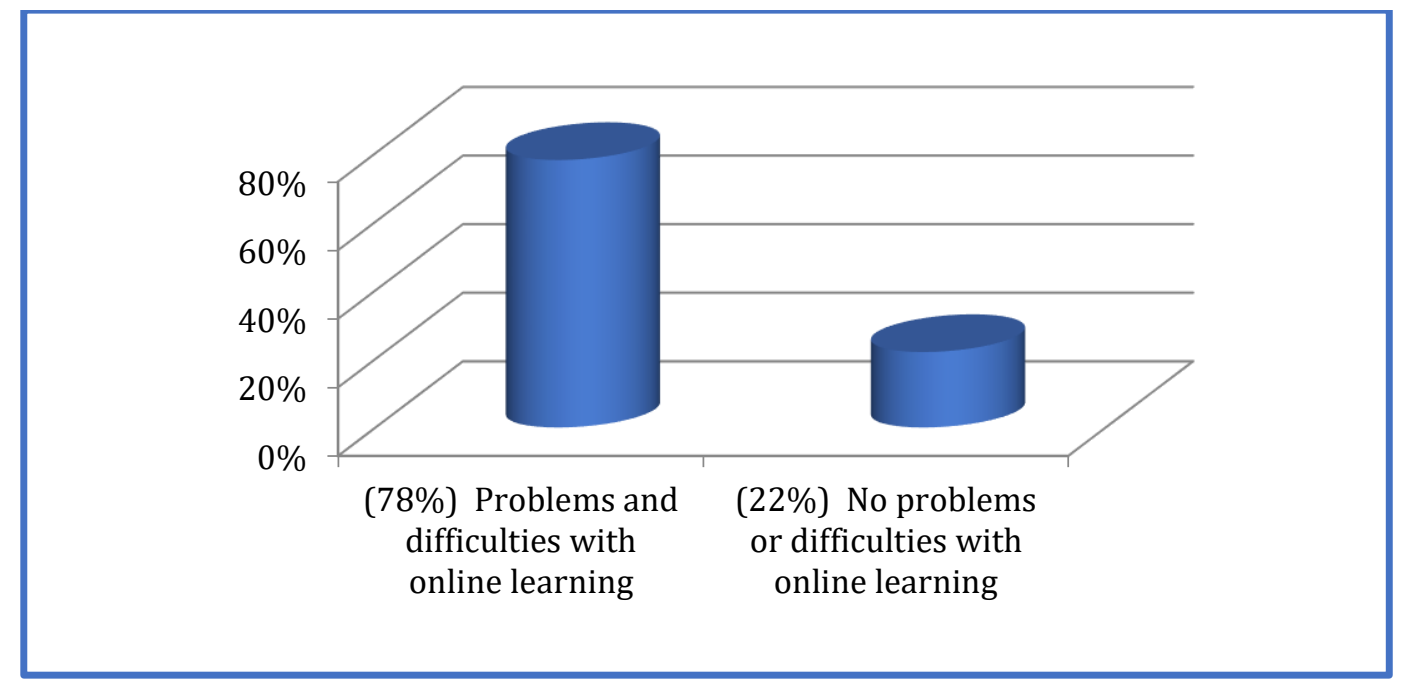

Figure 4: The percentage ratio between the students with and no problems/difficulties with online learning.

Most students (78\%) reported encountering problems or difficulties with online learning, and the rest (22\%) reported that they had not encountered any problems or difficulties. The nature of problems and difficulties that students had described in their answers fell into two categories, as presented in Figure 5.

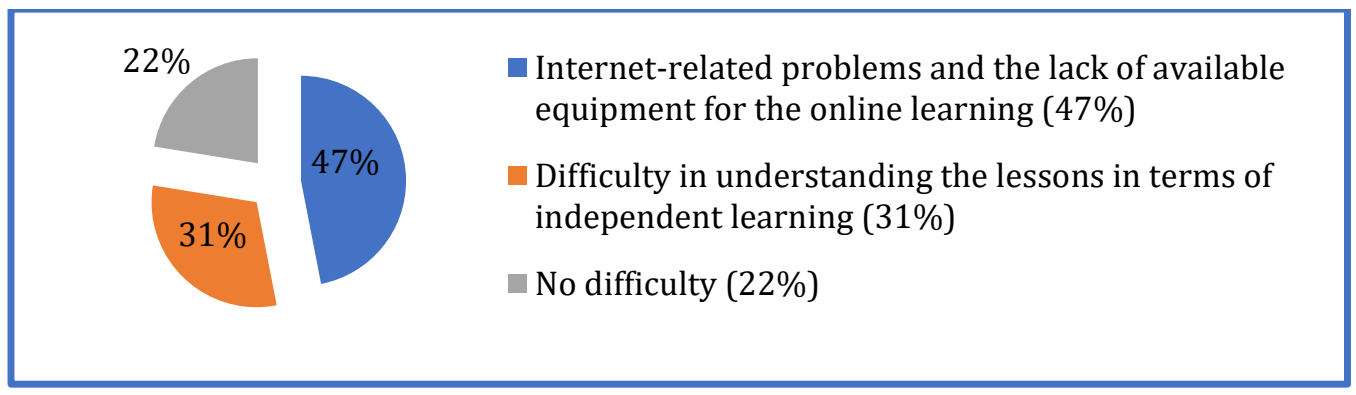

Figure 5: The nature of problems and difficulties that students faced with online learning. 
Approximately $47 \%$ of students reported having internet-related problems and difficulties caused by the lack of an available device to attend online learning, as follows:

Lack of internet connection at home;

Poor quality of internet distribution on various regions of country;

Lack of a personal computer (PC) or laptop to attend online learning at home conditions;

Low family income which does not allowed the students to benefit from purchase of telephone packages to navigate the internet;

Difficulty in using mobile phone during all hours of online teaching;

Writing and reading assignments for a long time on the small screen of mobile phone have caused eye strain, fatigue, frustration;

Inability to adapt quickly to the use of different online learning applications for different subjects, because one subject was taught in Google Classroom, others in Zoom Meeting or WhatsUpp or E-mail;

There are significant statements among students' answers to internet-related problems, such as:

"Online learning had its difficulties. Not all students have the financial means to secure a computer, laptop or continuous internet connection. Most students used cell phones because they did not have a computer at home".

"Of course online learning could be effective, but as long as most students do not have a laptop at home this complicates their learning process. How do you learn a topic or do a task with a phone? I have personally experienced eye strain every time I interacted with the small cell phone screen".

The lack of internet at home and available equipment for the online learning has exposed a significant number of students (approximately $47 \%$ of them) with unequal opportunities to participate in distance education.

While, $31 \%$ of students reported the difficulty in understanding lessons and assignments in terms of independent learning, such as:

Overloading with individual assignments by a part of professors;

Lack of online services by university library;

Difficulty in finding online literature to perform the individual assignments;

Need for additional explanations by professors about materials of their lectures;

Longing for classroom meeting and interactions with peers; 
Some of significant statements among students`answers regarding difficulties to learn independently are:

"In conditions of study from home we have worked only with reduced literature send by email by our professors. The university library still offers no possibility to use online textbooks".

"Doing lesson only with online way was not very effective, because the lack of necessary textbooks creates a very big gap in getting most complete knowledge".

"I suggest that online learning be done properly because otherwise it may not be effective. We were found overwhelmed with assignments while not having access to internet and tools needed to complete assignments".

"I hope to be back in auditorium as soon as possible and have the opportunity to meet my classmates and professors".

It seems that high number of assignments given for independent work in the context of online learning was perceived by a considerable part of students as overload. The lack of lecturer-student and student-student interaction has influenced them to take responsibility for their own learning. The lack of service in university library to provide online textbooks of various subjects may have pushed students to find other online sources to obtain information needed to complete assignments. All of this situation, as well as the need to interact with classmates, seem to have influenced students to perceive certain levels of difficulty in understanding lessons and performing assignments independently.

\section{Students` preferences towards the modes/forms of higher education delivery}

The results regarding students' preferences towards the modes/forms of higher education delivery (face-to-face, online, hybrid) are presented in Figure 6.

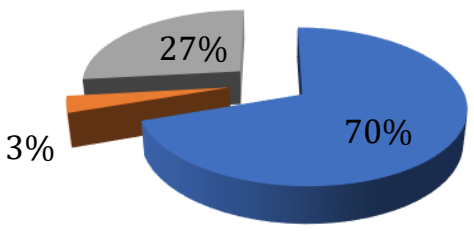

Face-to-face teaching in auditorium

Online learning

Hybrid form that combines face-to-face teaching with online learning

Figure 6: The students' preferences towards modes/forms of higher education delivery (face-to-face, online, hybrid).

As can be seen in Figure 6, the vast majority of students (70\%) had preferred the faceto-face teaching form in auditorium compared to online or hybrid teaching form. But, $27 \%$ of them had preferred the hybrid teaching compared to other forms. Only $3 \%$ of 
students had preferred the online learning form compared to teaching in auditorium and hybrid teaching form.

Among students' answers regarding their preference towards the forms of higher education delivery, a participant noted "I like online learning because I'm at work and cannot attend university class full time. During the period of pandemic, I benefited from online learning because it allowed me to manage my time to learn independently". Someone has written "I think that teaching in auditorium is more effective than online one. In class we have opportunity to listen to the professors' explanations and discuss with classmates about various subject matters". Another stated "Teaching in auditorium does not compare in terms of values with online teaching! There is no possibility in a virtual world to concretize the laboratory lessons or teaching practices". Others suggested "It would be better to combine teaching in auditorium with online learning".

As noted, partly students have showed a positive attitude towards the integration of online learning at university as a necessary approach in the digital society, but without underestimating face-to-face teaching.

It was possible that students` initial personal experience with online learning have influenced their attitude and preference for the most appropriate mode/form of higher education delivery (face-to-face, hybrid, online).

\section{Discussion}

The primary purpose of study was to examine students` perceptions of their online learning experience during the sudden transition from teaching in auditorium to online learning environment in conditions of social isolation caused by COVID-19. A further aim was to find out their preference for most appropriate form of higher education delivery (face-to-face, hybrid, online) for young people of digital age.

The study findings indicated that the biggest challenge for most of students was the immediate adaptation to the form of distance learning. Almost $77 \%$ of all students had perceived the online learning situation dominated more by negative experiences than positive ones, and only $23 \%$ of them had perceived the online learning situation as a positive experience.

Also, there were $78 \%$ of students in total who reported having encountered problems or difficulties with online learning, and the rest $(22 \%)$ reported that they had not encountered any problems or difficulties. The nature of problems and difficulties that students had described in their answers fell into two categories: 1) internet-related problems or difficulties caused by the lack of an available equipment/device to attend online learning (47\%), 2) the difficulty in understanding the lessons and assignments in terms of independent learning (31\%).

Statistical analysis of study data revealed a significant correlation between the value in percentage of students (78\%) who reported a range of problems or difficulties with 
online learning, and the value in percentage of students (77\%) who perceived online learning as a negative experience. The strong association between these two values can be considered as an important indicator of study reliability.

The positive and negative experiences such as those perceived by students in this study could also be explained not only in terms of advantages and disadvantages of online learning compared to face-to-face teaching or opportunities and digital skills that students had to attend online course from their home, but also by availability of university`s digital infrastructure to support distance education, as well as the capacity of academic staff to transfer immediately teaching courses from auditorium to the online space. Recent studies have suggested that an online class will be as effective as face-to-face class if it is designed appropriately (Nguyen, 2015).

Despite the internet-related problems and various difficulties, the transfer of teaching from auditorium to online environment has brought more focus to student-centered learning. Qualitative analysis of results derived from open-ended questions showed that the high number of assignments given for independent work and the lack of the subject textbooks offered online seems to have induced students to take more responsibility for self-direction of their learning process. Previous research has pointed out that students who have this sense of responsibility tend to have positive online learning experiences (Blackmon, S.J., and Major, C., 2012). However, e-learning may lack real interactions between instructors and students (Mansour, B.E., Mupinga, D.M., 2007).

According to study results, $31 \%$ of students reported the difficulty in understanding lessons and assignments in terms of independent learning, especially in cases where in the online learning context the lecturers had increased the amount of academic workload for their students and where there was a lack of instructional interaction between lecturer and students. Given that independent learning is essential prerequisite not only for the management of online learning but also for lifelong learning it is very important to be cultivated in students. To succeed in an online learning environment, instructors should implement good teaching through good online course design, provide thorough explanations, define goals clearly and seek continued feedback from students (Crews, Kelly, et al., 2015). ${ }^{1}$ Several studies have noted that instructors also have a strong influence over student experience, in large part through their accessibility and through their efforts to provide opportunities to connect with peers (Blackmon, S.J., Major, C., 2012). In this framework the online teaching model may have the potential to improve the quality of university learning in the future, but it need to be seen more carefully before it is applied.

Regarding web-based applications used for online learning, the majority of respondents (64\%) reported that Google Classroom was the most frequently used. It was a surprising finding the use of social media platforms, such as WhatsUpp, E-mail

${ }^{1}$ Cited from Carnasciali,M., Erdil,N., 2020 
and Video Call, for online learning purposes. The use of such social media may be seen by lecturers as an easy quick way to communicate with students, rather than as an effective opportunity to teach online. However, these approaches may be a potential for further research in future.

Although the experiences with online learning platforms were new in faculty, the analysis of findings showed a much higher dominance of student population (87\%) who admitted that they had a high level of digital competence compared to student population (13\%) who admitted that they did not possess it sufficiently.

Since the success of online learning depends primarily on mastery of digital competence, this result can also be seen as a significant indicator of the readiness of the majority of students to attend the web-based learning courses in future. However, there are other factors identified by research that influence the student readiness for online learning such as self-directed learning, self-efficacy, digital engagement, and motivation for learning (Doe, at al., 2017).

The data analysis showed that a vast majority of students $(70 \%)$ preferred face-toface teaching and a minority of them (30\%) preferred other forms that integrate online technology. There may be a number of reasons why students showed an extremely strong preference for teaching in auditorium. However, it seems that this choice has been largely influenced by problems and difficulties they encountered during immediate transition from face-to-face teaching to online learning, where according to present results of study, almost $77 \%$ of all students had perceived the new situation of online learning dominated more by negative experiences than positive ones, as well as $78 \%$ of all students had reported problems or difficulties with online learning. While the rest of respondents (30\%) who showed more preference for the hybrid or online teaching/learning forms seems to have been able to explore or appreciate some of the advantages of distance education offered by university during the period of social isolation caused by COVID-19 pandemic.

It is known from research that online learning offers several advantages over traditional classroom learning. Among these are the elimination of barriers of time and space. The online learning environments offer flexibility of instructional pace, and more control over which learning activities are more appropriate to engage in (Alexandra, 1996). ${ }^{1}$ In contrast to these findings many still feel that online learning excludes some within society, the poor/less well-of, the socially disadvantages, who are unable to effort the equipment that is essential to this mode of study. The arguments against online learning are focused mainly on the concern for loss of traditional classroom face-to-face interaction, and potential feelings of isolation (O`Donoghue, et al., 2004).

\footnotetext{
${ }^{1}$ Citet from Mansour,B.E., Mupinga,D.M.,2007
} 


\section{Conclusions and Recommendations}

This study is in line with other studies which have contributed to the idea that student opinion is essential for improving quality of distance learning in the higher education system.

Hence, the findings of present study on the favorable and unfavorable perceptions by students regarding online learning can be considered as important indicators of quality of teaching transfer from classroom to the online environment. However, some recent studies focusing on educational situation influenced by COVID-19, have suggested that this new experience should not be seen as a threat by students and educational institution based on conventional teaching, but should serve to adapt the benefits of online education system to their teaching (Ramirez-Hurtado, et al., 2021).

The study concluded that the new reality created by COVID-19 tested the current capacity of higher education institutions regarding the ICT integration process in teaching. As this process was progressing very slowly, universities in countries like Albania were found unprepared to transfer the teaching process from the auditorium to the online environment with the same quality.

Therefore, the academic initiatives to apply in the near future a full approach to online teaching still seem difficult. However, more research is needed to examine the current needs of higher education institutions in Albania regarding the improvement of infrastructural conditions that support distance education as well as training needs of lecturers about adapting the course content and developing innovative materials and methods to deliver online teaching.

The evolution of online instruction and continuous search to incorporate the best educational methods from both traditional and virtual environments has led to many institutions adopting a "hybrid," also known as blended learning (Dziuban, et al., 2004). The goal of blended learning should be to unite the best features of in-class teaching with the best features of online learning, to promote active, self-directed learning opportunities for students (Garnham \& Kaleta, 2002) ${ }^{1}$

In order to meet the demands of the future, the recent studies have recommended that every university should set up in its strategy clear and concrete goals towards its digital transformation, taking into consideration three main areas: its digital infrastructure, the development of its academic staff s skills to use digitally-based methods in their teaching and the improvements of its students' digital skills (Grosseck, G., Malita, L., Bunoiu, M., 2020).

${ }^{1}$ Cited from Joutsenvirta,T., Myyry,L.,2010 


\section{Limitations}

This study has some limitations which can affect generalizing study results in other contexts. The participants in study were students of a faculty at University of Elbasan, Albania. If the study had been extended to other universities of country, than results of study could have been different. Also, the study is carried out in a very short period of time attempting to take a snapshot of a changing situation. Students perceptions can change over time. The recorded results are limited to time, place and culture where the study was conducted. However, this study may serve to promote in future the further studies on online learning at university.

\section{Acknowledgements}

I am really grateful to all respondents who spent their valuable time filling the study questionnaire even though it took place in an emergency pandemic situation from Covid-19.

\section{References}

[1] Arias J. J., Swinton, J., \& Anderson, K. (2018) Online Vs. Face-to-Face: A Comparison of Student Outcomes with Random Assignment, e-Journal of Business Education \& Scholarship of Teaching, 12(2) http://www.ejbest.org

[2] Blackmon, S.J., Major, C. (2012) Student experiences in online courses. A qualitative Research Synthesis. The Quarterly Review of Distance Education, 13(2) https://www.cu.edu/doc/student-experiences-onlineclassesqual-study.pdf

[3] Boettcher, J.V., Conrad, R.M.,(2010) The online teaching survival guide: simple and practical pedagogical tips, Published by Jossey-Bass, San Francisco, https://www.mobt3ath.com/uplode/book/book-59307.pdf

[4] Carmo, R. O.S., Franco, A. P.(2019) From face-to-face teaching to online teaching: the learning of university teachers in distance education, EDUR Educação em Revista http://dx.doi.org/10.1590/0102-4698210399

[5] Carnasciali, M., Erdil, N.O.(2020) Student and Faculty Perceptions of Integrated E-learning Modules Aimed at Developing an Entrepreneurial Mindset, American Society for Engineering Education, file://C:/Documents\%20and\%20Settings/User/My\%20Documents/Dow nloads/student-and-faculty-perceptions-of-integrated-e-learning-modulesaimed-at-developing-an-entrepreneurial-mindset.pdf

[6] Devine, J., Gordon, M.(2020) Cultivating Community: Constructivist Online Learning in a Teacher Leadership, Program International Journal of Social Policy and Education, 2(2);

file://C:/Documents\%20and\%20Settings/User/My\%20Documents/Dow nloads/CultivatingCommunityessay.p 
[7] Doe, R., Castillo, M. S., \& Musyoka, M.M.(2017) Assessing online readiness of students. Online Journal of Distance Learning Administration, 20(1), https://www.westga.edu/ distance/ojdla/spring201/doe_castillo_musyo ka201.html

[8] Dumford A.D., Miller A.l.(2018) Online learning in higher education: exploring advantages and disadvantages for engagement, Journal of Computing in Higher Education, 30(6)

https://www.researchgate.net/publication/324189732_Online_learning_in _higher_education_exploring_advantages_and_disavantages_for_engagemen $\mathrm{t}$

[9] Glossary of Online Learning Terms (2019) Connie Malamed, http://theelearningcoach.com/resources/online-learning-glossary-ofterms/

[10] Grosseck G., Malita L, \& Bunoiu M. (2020) Higher Education Institutions Towards Digital Transformation-The WUT Case (Conference paper) Europian Higher Education Area: Challenges for a New Decade. https://doi.org/10.1007/978-3-030-56316_35

[11] Joutsenvirta,T., Myyry, L.(2010) Blended Learning in Finland, Published by: Faculty of Social Sciences at the University of Helsinki http://citeseerx.ist.psu.edu/viewdoc/download?doi=10.1.1.469.3691\&rep $=$ rep $1 \&$ type $=$ pdf

[12] Kebritchi, M., Lipschuetz, A., \& Santiague, L.(2017) Issues and Challenges for Teaching Successful Online Courses in Higher Education: A Literature Review Journal of Educational Technology Systems, 46(1), file://C:/Documents\%20and\%20Settings/User/My\%20Documents/Dow nloads/OnlineCoursesIssueandChallenges0047239516661713\%20(1).pdf

[13] Mansour, B.E., Mupinga, D.M.(2007) Students' positive and negative experiences in hybrid and online classes, College Student Journal, 41(1), https://www.researchgate.net/publication/285634575_Students'_positive _and_negative_experiences_in_hybrid_and_online_classes

[14] Nguyen, T.(2015)The effectiveness of online learning: Beyond no significant difference and future horizons, Journal of Online Learning and Teaching. 11(2), 2015 https://www.researchgate.net/publication/308171318_The_Effectiveness _of_Online_Learning_Beyond_No_Significant_Difference_and_Future_Horizo ns

[15] O`Donoghue, J., Singh, G., Green,C.(2004) A comparison of the advantages and disadvantages of IT based education and the implications upon students, Interacitve Educational Multimedia, 9, file://C:/Documents\%20and\%20Settings/User/My\%20Documents/Dow nloads/Dialnet-

AComparisonOfTheAdvantagesAndDisadvantagesOfITBase-4544753.pdf 
[16] Ramirez-Hurtado, J.M., Hernándes-Diaz, A.G., López-Sánchez, A.D., PérezLeón, V.E.(2021) Measuring Online Teching Service Quality in Higher Education in the COVID-19 Environment, International Journal of Environmental Research and Public Health, file://C:/Documents\%20and\%andSettings/User/My\%20Documents/Do wnloads/ijerph-18-02403-v2\%20(1).pdf

[17] Rampelt, F., Orr, D., \& Knoth, A.(2019) Bologna Digital 2020 https://hochschulforumdigitalisierung.de/sites/default/files/dateien/201 9-05_White_Paper_Bologna_Digital_2020_0.pdf

[18] Seaman J.E., Allen I.E., \& Seaman J.(2018) Grade Increase:Tracking Distance Education in the United States, Babson Survey Research Group, https://bayviewanalytics.com/reports/gradeincrease.pdf

[19] Skibba K., Ndon, U.(2006) Using a Hybrid Intructional Model in Teancing and Learning. Adult Education Research Conference. https://newprairiepress.org/aerc/2006/roundtables/14

[20] Venable, M.A.(2020) Online Education Trends Report, https://res.cloudinary.com/highereducation/image/upload/v1584979511 /BestColleges.com/edutrends/2020-Online-Trends-in-Education-ReportBestColleges.pdf 